\title{
Gypsum speleogenesis: a hydrogeological classification of gypsum caves
}

\author{
José-María Calaforra $^{1^{*}}$ and Fernando Gázquez ${ }^{2}$ \\ ${ }^{1}$ Water Resources \& Environmental Geology, CAESCG, University of Almeria, Ctra San Urbano s/n, 04120 Almeria, Spain \\ ${ }^{2}$ School of Earth and Environmental Sciences, University of St. Andrews, St Andrews, KY16 9AL, Scotland, United Kingdom
}

\begin{abstract}
This article reviews the state of the art of speleogenetic investigations in gypsum karsts from numerous studies carried out over the past 50 years in Spain. A classification of gypsum karsts is proposed based on the hydrogeological, tectonic and stratigraphic criteria that decisively control the evolution of gypsum karsts. In this respect, lithological aspects of Messinian and Triassic-Permian gypsum series in south-eastern Spain are considered, such as the alternation of rhythmic levels of marl and gypsum, as well as geodynamic aspects. The influence of the hydrogeological characteristics of evaporite aquifers on gypsum cave speleogenesis is discussed; this includes speleogenetic processes in confined, semi-confined or free aquifers controlled by regional and local base levels. Also, the importance of intense saline diapiric uplift is examined. To illustrate our classification, examples of gypsum caves developed in Spain are presented. Their similarities and differences with gypsum karsts in other regions (Italy, Ukraine, and USA) are discussed. A first general division addresses: (1) caves controlled by stratigraphic factors and (2) caves controlled by tectonic factors. Several typologies can be described, including (A) multilayer caves with confined hydrogeological origin, (B) confined hypophreatic caves with linear or maze configurations, $(C)$ caves controlled by the variation or remanence of regional or local base-levels, and (D) caves controlled by the halokinetic evolution of salt/gypsum diapirs. The proposed classification is flexible and adaptable to each case, because different genetic mechanisms can coincide in time and space. Likewise, most considerations stated in this work about gypsum karst are valid for speleogenesis in other rock types.
\end{abstract}

Keywords: $\quad$ caves, gypsum, karst, speleogenesis

Received 1 April 2017; Revised 2 June 2017; Accepted 2 June 2017

Citation: Calaforra J.M. and Gázquez F., 2017. Gypsum speleogenesis: a hydrogeological classification of gypsum caves. International Journal of Speleology, 46 (2), 251-265. Tampa, FL (USA) ISSN 0392-6672 https://doi.org/10.5038/1827-806X.46.2.2125

\section{INTRODUCTION}

The present article summarizes the knowledge compiled over recent decades on the speleogenetic processes of the main gypsiferous areas in the Betic Range (Southern Spain). This region hosts significant gypsum outcrops of Triassic and Neogene age that have been affected by a wide variety of karstic processes (Fig. 1). We examine several gypsum karsts in this region to exemplify the most common morphologies and speleogenetic processes in gypsum, to generate a classification of gypsum karst on the basis of hydrogeological, morphological and tectonic criteria.

Based on their geodiversity and speleogenesis, the following caves were used as examples: the gypsum caves of "Covadura" and the "Barranco del Infierno" in the Sorbas gypsum karst (Almeria); the "Sima del Águila" Cave in the gypsum karst of Gobantes-Meliones (Málaga) and the "Cueva del Yeso" of Baena (Córdoba).
Each of these cavities shows particular features that suggest different speleogenetic mechanisms were involved in their evolution. Although these processes are intrinsically linked to local/regional geological and hydrogeological aspects (e.g., lithology, external geodynamics), these gypsum karsts show common elements with other gypsum areas worldwide (i.e., Italy, Ukraine, and USA). Therefore, the possible existence of common speleogenetic mechanisms with other gypsum karst is also discussed here.

\section{CAVE MORPHOTYPES - EXAMPLES OF GYPSUM SPELEOGENESIS}

The geomorphological characteristics of the various areas have been described in various compilation publications on Spanish gypsum karst (Calaforra \& Pulido-Bosch, 1996; Calaforra et al., 2002; Gutiérrez, et al., 2008; Sanna et al., 2012, 2015; Gázquez \& 

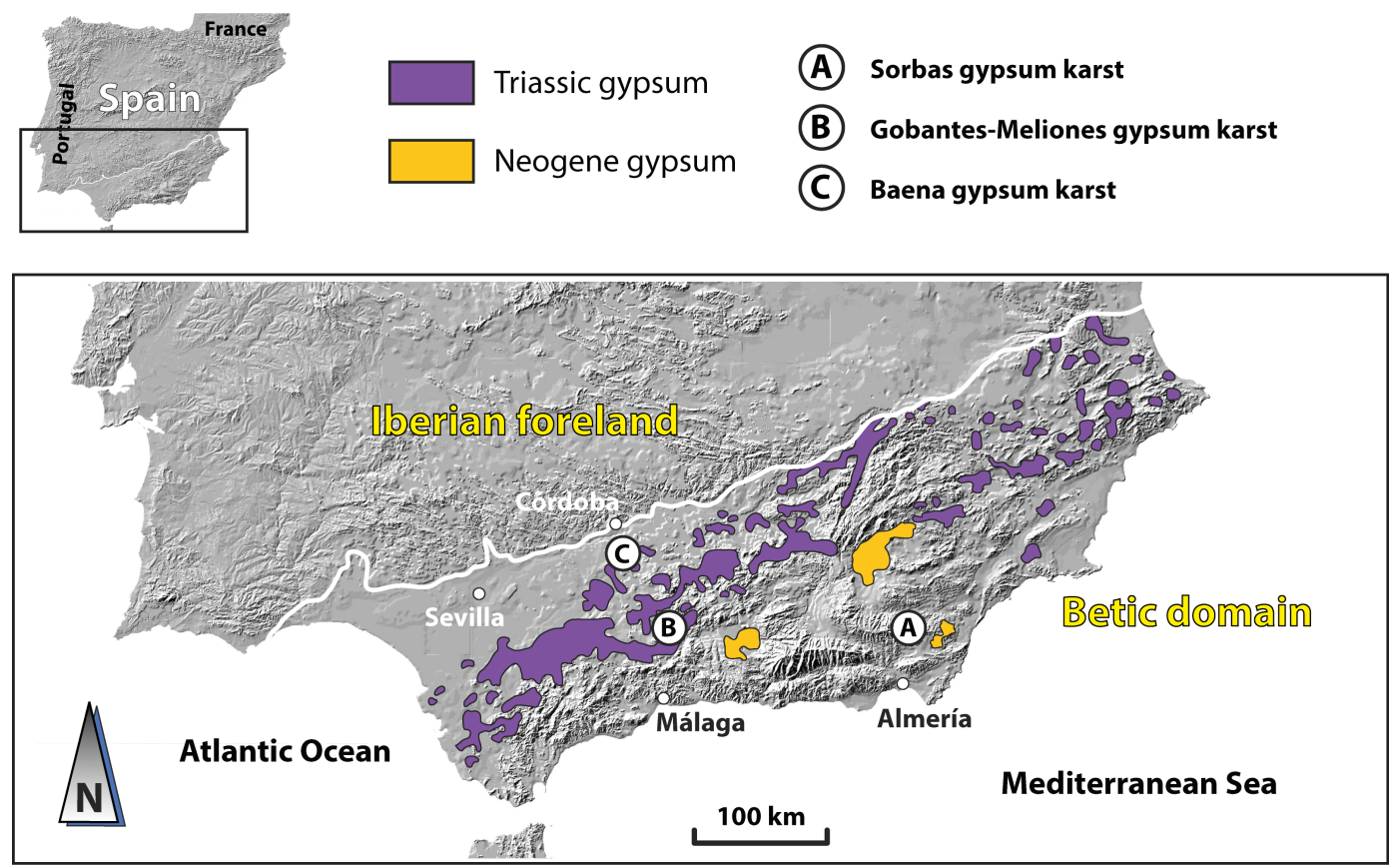

Fig. 1. Triassic and Neogene gypsum outcrops in the Betic mountain range. The selected areas and caves are A) Gypsum Karst of Sorbas (Covadura and Barranco del Infierno caves); B) Gobantes- Meliones karst (Sima del Águila); C) Baena gypsum Triassic outcrops (Cueva del Yeso).

Calaforra, 2014; Gázquez et al., 2015; Calaforra et al., 2015). Many studies have demonstrated the strong link between the hydrogeology and geomorphological evolution of these areas (e.g., Calaforra \& Pulido, 2003). This is even more evident in the case of gypsum karst speleogenesis with respect to karstification in other rock types. The connection between geomorphological features and their genetic processes is the basis of the classification proposed in this paper.

The caves described in this study cover the main types of gypsum outcrops, of both the Triassic and Messinian materials in the Betic Domain (Fig. 1). In terms of hydrogeology, examples of vadose and phreatic evolution are presented. The current morphology of the galleries includes examples of variations in piezometric level and regional base level, as well as tectonic aspects related to halokinesis, defined as the uplifting of salt masses (usually halite), which are relatively less dense than the surrounding geological materials. In this respect, there is a wide range of situations, but it must be considered that it is always possible to find mixed speleogenesis in the examples given, and so the short explanation of each example should be considered as an oversimplification to provide a very simple and unpretentious general model.

\section{Covadura: an interstratified cave}

The gypsum karst of Sorbas is located in the province of Almeria (SE Spain), with an outcrop area of some $12 \mathrm{~km}^{2}$ and up to 1,000 catalogued caves (Calaforra, 1995; Calaforra \& Pulido-Bosch, 1996; Calaforra et al., 2002). It lies within a topographic depression bounded on the north by the Filabres Mountains and on the south by those of Alhamilla and Cabrera. The region has a semi-arid climate, with a mean annual precipitation of less than 250 $\mathrm{mm}$ (Calaforra \& Pulido-Bosch, 1988). It is located within the Sorbas-Tabernas intramountain basin, part of the Betic Cordillera. The series consists of a cyclic sequence of interlayered gypsum and peliticmarly beds, called the Yesares Member (Dronkert, 1976, 1977).

Covadura Cave is one of the largest gypsum caves in Spain. With more than $4 \mathrm{~km}$ of explored galleries (Calaforra, 2003b), it crosses the Messinian series of the Yesares Member, reaching a depth of ca. 120 $\mathrm{m}$ (Calaforra, 1995). In the gypsum series in which the cave is developed, massive selenitic gypsum strata alternate with marly strata. This arrangement of sedimentary beds has a great influence on the morphology of the cave. It is without doubt, one of the most peculiar caves in terms of its speleogenesis (Calaforra \& Pulido-Bosch, 2003). The cave is developed in six levels following the stratification planes between marls and gypsum. Indeed, the horizontal sections of the cave coincide with the marl-gypsum contacts (Fig. 2A). The vertical sections correspond to vertical shafts that cross the massive selenitic gypsum strata and interconnect the various strata-levels of the cave (Fig. 2B). The general plan of the cave survey resembles "octopus-braided" limbs at different levels (Fig. 3). This is due to the vadose erosion of the interbedded marly strata following the dip slope of the strata themselves (Fig. 2D).

The speleogenesis of the cave is due to the evolution of a multilayer aquifer (Calaforra \& PulidoBosch, 2000). Figure 3 shows the formation of the protoconduits (Fig. 2A and C) with their phreatic tube morphology, which have developed at different levels of the aquifer marked by the interval between each gypsum stratum and the pelitic/marly stratum immediately beneath. In this way, an entire network of protoconduits (Fig. 3.1) developed, which are well isolated hydraulically, or at times linked by diaclases and intersections of vertical fractures. Under these conditions, dissolution of the gypsum predominated over erosion of the pelitic materials (Fig. 3 profile A). 

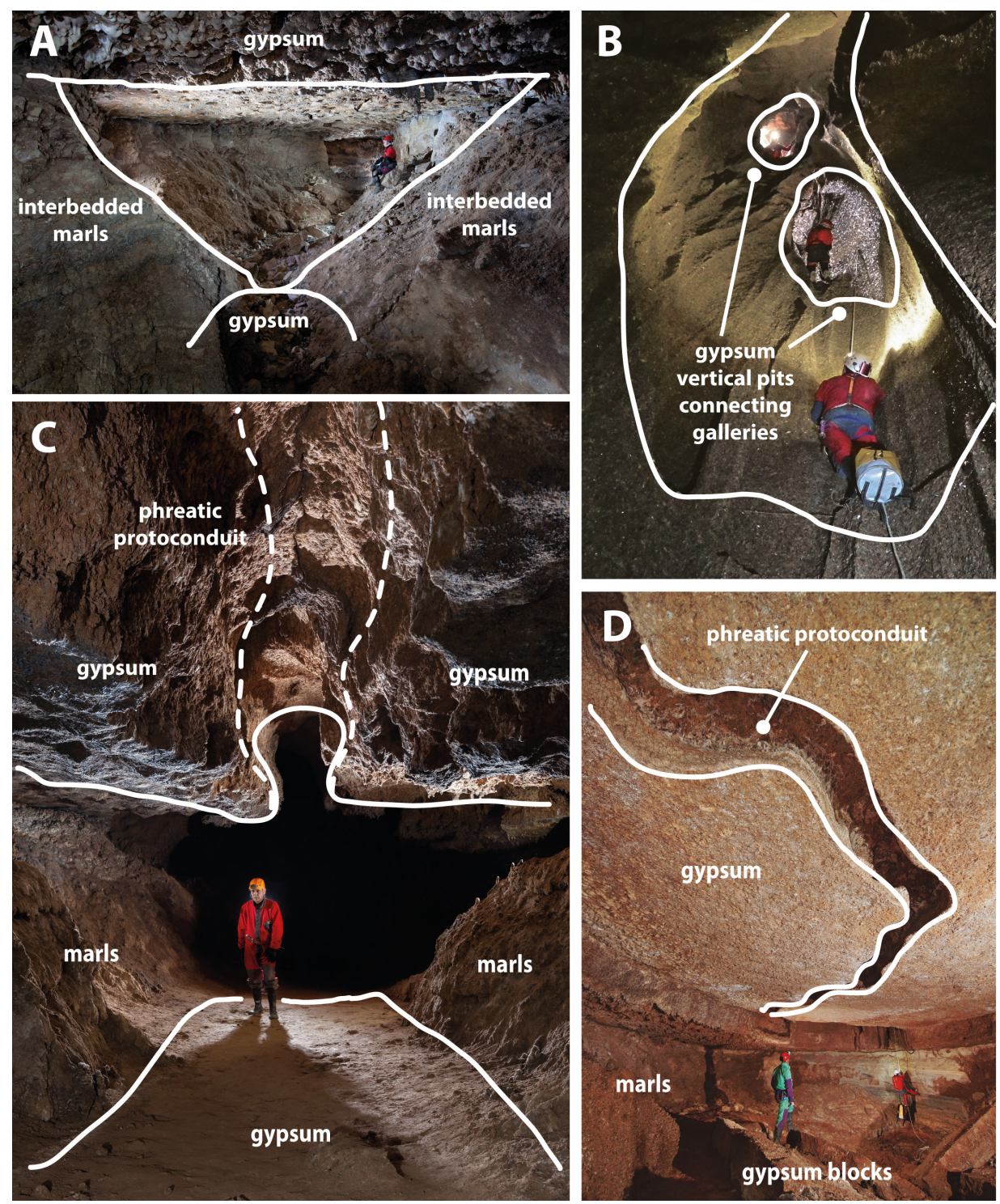

Fig. 2. Interstratification galleries in the Covadura Cave and other interstratal cave systems in the gypsum karst of Sorbas. The roof and floor of the gallery are made of gypsum, while the gallery itself develops in the marly-silty interstratum. A) Typical triangular cross section in a vadose-erosion gallery; B) The different horizontal levels are connected by shafts which can reach up to $40 \mathrm{~m}$; C) Some galleries have preserved protoconduits in the ceiling as evidence of the early phreatic stages in the speleogenesis of the cave; D) The protoconduits have a meandering path and follow the dip of the gypsum strata. Photos by Paco Hoyos ( $A$ and $C$ ) and Víctor Ferrer (B and D).

This initial speleogenetic phase occurred when the base level of the Sorbas aquifer was tens of meters above the current groundwater level. Erosion and incision of gullies (see next section about Barranco del Infierno) caused the lowering of the regional phreatic level.

As a result of the lowering of the phreatic level, a second stage occurred when the aquifer gradually changed to vadose conditions. The underground network, which initially would have been practically isolated from the surface network, began to receive vadose infiltration from the numerous dolines that were forming on the surface, both by sinking and collapse and by dissolution.

The galleries receiving these vadose waters began to enlarge and the cave developed within the interstrata. Erosion dominated over dissolution and the galleries enlarged due to erosion of the detrital, partially unconsolidated, interstratified layers (Fig. 3 profile B). The detrital materials were swept out to the surface and into the canyons. These erosional processes are still active in the gypsum karst of Sorbas, as evidenced by high turbidity of the springs that drain the karst (e.g., Viñicas-Marchalico/Cueva del Agua spring) after extreme rainfall events (Dell'Aglio, 1993) and movements of sediments in caves after flash flood events (Gázquez et al., 2016).

Covadura Cave could be considered as an exceptional natural laboratory to observe the relationships between early phreatic processes in gypsum and extreme vadose incisions in marls.

The various levels became interconnected by means of large sinkholes that cross one or several gypsum strata at a time (Fig. 3 profile B). The lower levels of Covadura and the narrow lateral passages along the contacts with the marly interstrata still preserve the morphology of the protoconduits, while in the large erosive galleries, with their typically triangular morphology, the protoconduits appear on the roof in the form of ceiling channels.

In addition to Covadura Cave, the gypsum karst of Sorbas hosts other clear examples of interstratified 

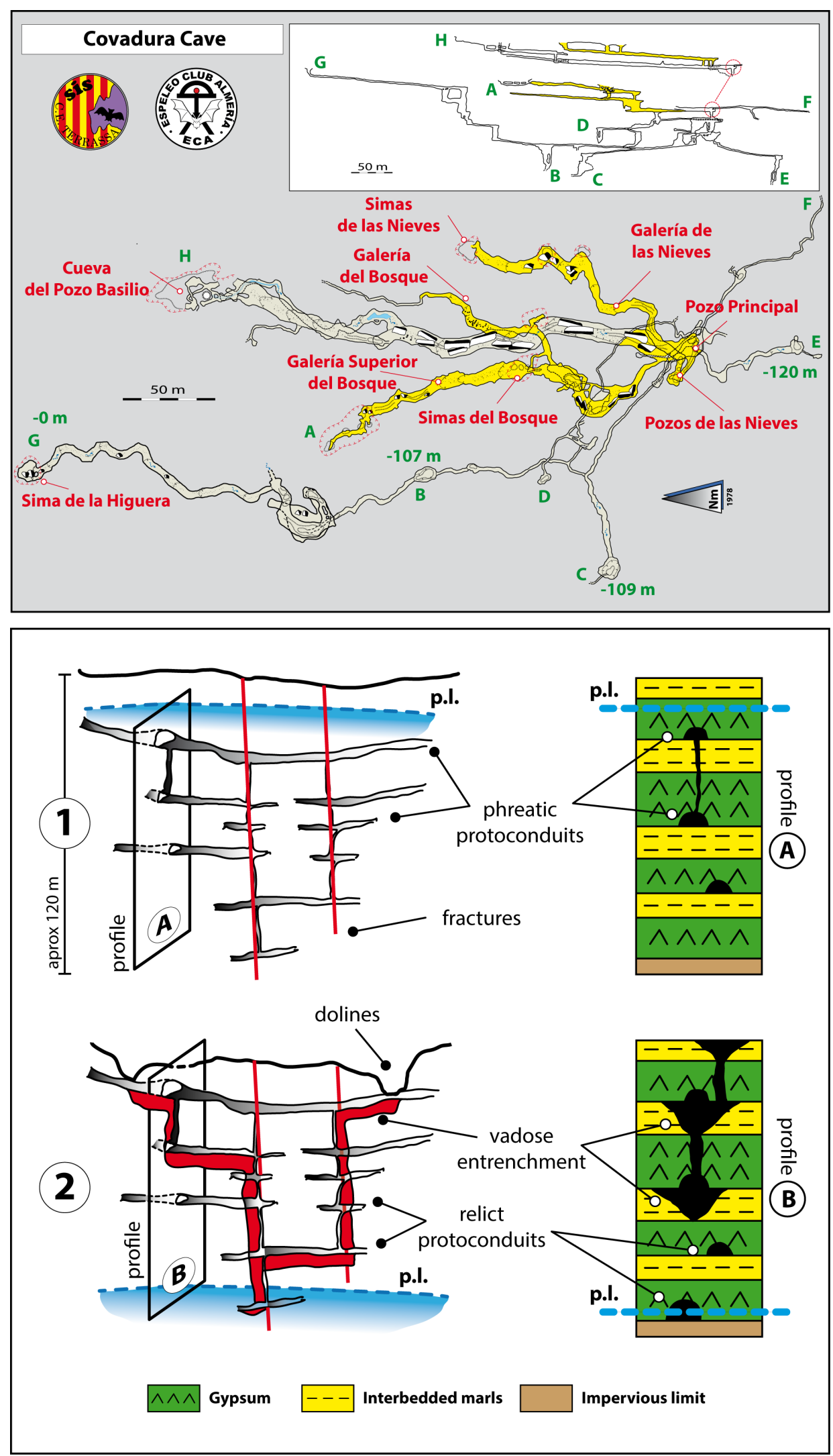

Fig. 3. Evolution of the interstratal gypsum karst, using the example of Covadura Cave. Above: present survey plan of Covadura Cave (Ayuso et al., 2014) showing the wide vadose galleries connected by phreatic protoconduits. Below: 1): in a multilayer aquifer under phreatic conditions the protoconduits are formed along the stratigraphic contacts between the gypsum and marls (profile A); 2): under vadose conditions, the marly layers only in some galleries are eroded and the different levels become connected via shafts traversing the gypsum strata (profile B). The speleogenesis is closely linked to the hydrogeological evolution (p.l. = piezometric level) and the lithological constraints of the gypsum-marls rhythmic series). 
caves that show similar geomorphological and speleogenetic evolution, such as Sima del Corral and Sima del Campamento (Ayuso et al., 2014) and C3 Cave (Gázquez et al., 2015), among others.

\section{Cueva del Barranco del Infierno: a fluvio-karstic cave}

Another example of the speleogenetic evolution of the gypsum karst of Sorbas is the fluvio-karstic complex of Barranco del Infierno ("barranco" = gully, ravine). The gypsum fluvio-karst morphology in this zone is characterized by deep and subvertical walls (Fig. 4A and B) generated by the combined action of fluvial erosion and karst dissolution linked to the progressive fall of the piezometric and fluvial base level (Braga et al., 2003; Calaforra, 2003a).

The fluvial network was established at an early stage, according to the structural and lithological conditions of the area (Fig. 5.1), where only two main gypsum strata and one interbedded marl bed coexist above the impervious marl level of the Abad Member Late Miocene (Baggley, 2000).
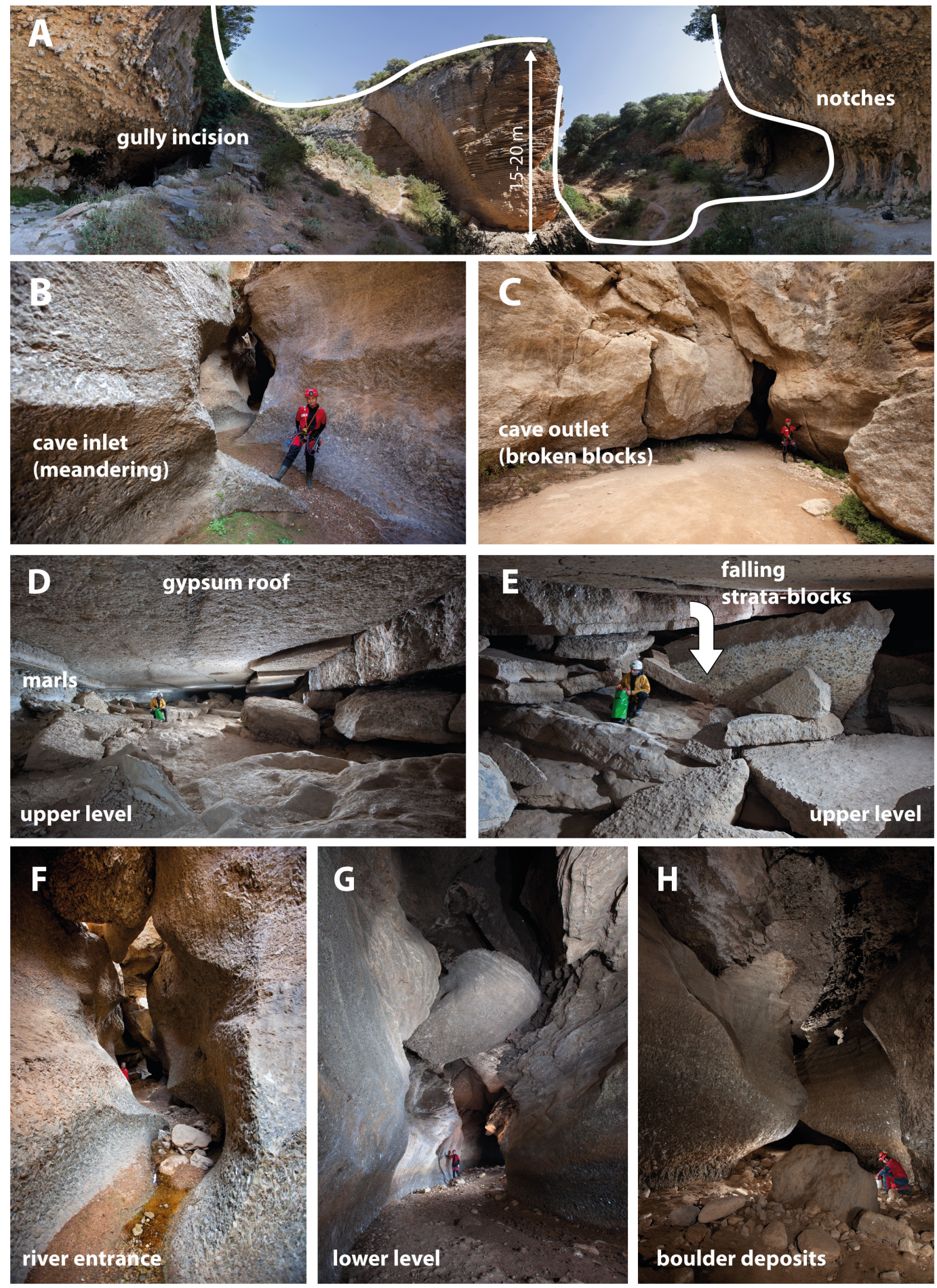

Fig. 4. Surface and underground morphologies of the Barranco del Infierno and Cueva del Yeso (gypsum karst of Sorbas). A) Gully incisions and perched notches due to the falling of the local base level; B) The upstream capture of the main gully by the cave entrance; $C$ ) the outflow of the cave consists of a temporary spring with large, falling unstable blocks; D) 'Stratified Chamber' of the Cueva del Yeso where the marly strata have been eroded; E) the configuration of galleries at times relates to collapses of large layers of gypsum, destabilized by the erosion of the marl levels; $\mathrm{F}$ to I) the lower level of the cave looks like a surface stream canyon with vertical walls and rounded boulder deposits. Photos by Paco Hoyos. 
The area is covered by the Sorbas Member, postevaporitic Messinian sandstones and silts (Dabrio $\&$ Polo-Camacho, 1995) and separated from the Yesares Member by a significant subaerial erosion (or sedimentation hiatus) at $5.6-5.46 \mathrm{Ma}$, caused by the almost complete desiccation of the Mediterranean Sea before the practically instantaneous marine reflooding, accepted at $5.46 \mathrm{Ma}$, and subsequent, continuing sea-level rise (Clauzon \& Estrada, 2015).
Probably, the first karstification processes under phreatic conditions started in this early stage.

After the incision of the gullies, the upper gypsum strata started to crop out and the capture of the main gully transformed the stream into a blind valley and underground river. Dolines began to form at the bottom of the perched gullies, connecting the cave with new surface entrances (Fig. 5.2).
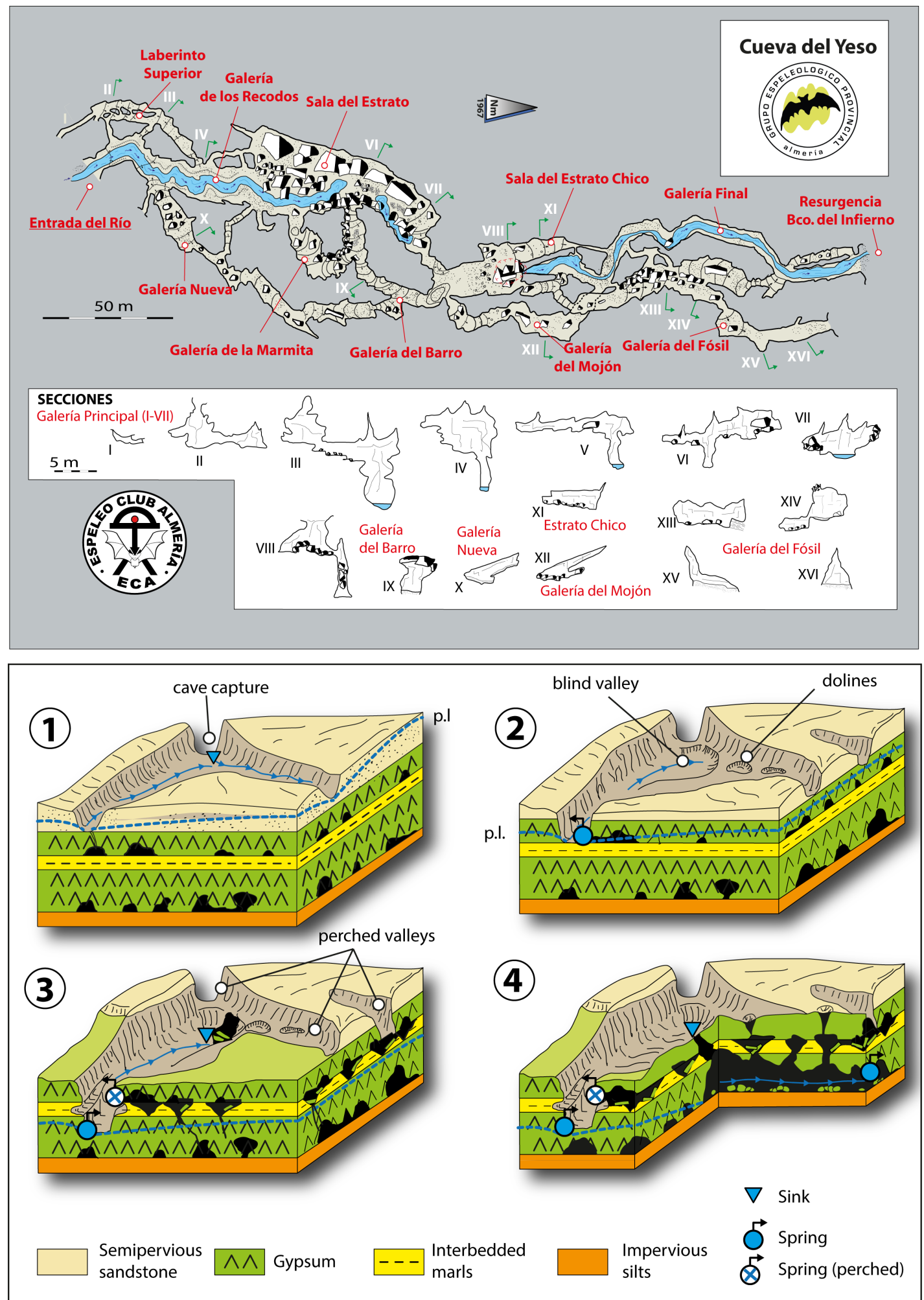

Fig. 5. Evolution of a fluvio-karstic cave, using the example of the Barranco del Infierno (known as Cueva del Yeso). Above: cave survey plan projection of the Cueva del Yeso (Ayuso et al., 2014) showing the lower river-active level and upper galleries. Some cross sections of the cave show both levels (see also photos in Fig. 4). Below: block diagrams showing the fluvio-karstic evolution. (1): fluvial erosion of the overlying materials; (2): formation of blind valleys and dolines; (3): cave capture of the stream, fall of the piezometric level, perched valleys and springs, erosion of the upper level of galleries; (4) view of the underground structure of the fluvio-karstic cave and relationship to surface morphology. 
Gradually, the fluvial network incised due to local intensification of karst dissolution processes and erosion. Some fluvial courses evolved rapidly and remained active while others progressed to dry perched barrancos, abandoned by the permanent streams (Fig. 4A and Fig. 5.3). Today, the water flow can reach peaks of up to $1 \mathrm{~m}^{3} / \mathrm{s}$ after extreme rainfall events, which are relatively frequent in this area (Gázquez et al., 2016).

Groups of galleries appeared in the upper strata, whose genesis was related to the progressive fall of the base level and consequent erosion of the marls (Fig. 4D and 5.3). After the fall in piezometric level, these thick strata became unstable and chaotic chambers with huge strata-blocks were formed (Fig. 4E).

The Barranco del Infierno and Cueva del Yeso constitute the most notable and clear examples of fluvio-karstic evolution in the gypsum karst of Sorbas. Cave captures, gully incisions, blind valleys, perched streams and springs give clear evidence for speleogenesis connected to the dynamics of the local groundwater base level (Fig. 5.4).

\section{Águila Sinkhole: Halokinesis, diapirism, and gypsum caves}

Most outstanding evaporite karst systems developed in the western sector of the Betic Cordillera are found in certain halokinetic formed developed in the so-called "Triassic of Antequera" (Carrasco et al., 2007). This geological unit corresponds to a chaotic megabreccia with gypsum bodies at the ground surface and halite and gypsum/anhydrite masses at depth, derived from Triassic formations in Miocene times by olistostromic processes (Pérez-López \& Sanz de Galdeano, 1994; Rodríguez-Fernández et al., 2013).

The Sima del Águila (Fig. 6A) is the finest example in Spain of a cave whose genesis was dominated by the effects of diapiric activity, both from mechanical (tectonic) and morphological (speleogenetic) points of view. This cave reaches $120 \mathrm{~m}$ in depth and contains a chamber $25 \mathrm{~m}$ high and some $200 \mathrm{~m}^{2}$ in extent (Fig. 6A and 6B). The sinkhole opens at the top of the Gobantes diapir, which is composed of large olistostromic blocks. These large-scale landslides and possibly a large proportion of the diapiric activity - occurred in the Miocene, though the materials that comprise the large blocks are essentially Triassic.

Among the Triassic materials that comprise the diapir are saccharoid masses of gypsum which, in turn, contain blocks and pebbles of dolomite, ophite, marly limestone, limestone and gypsum itself. The overall appearance of the hostrock in which the cave has formed is, therefore, a tectonic breccia of variable lithology within a gypsum matrix (Fig. 6.3).

A close relationship between the geological structure and the karst morphology and hydrochemistry has been documented in several evaporitic outcrops, like Gobantes-Meliones and Salinas-Fuente Camacho (Calaforra \& Pulido-Bosch, 1993, 1999). The Gobantes-Meliones outcrop, where the Sima del Águila is developed, consists of two dome structures with sandstones, limestones and ophites in the outer zones, and evaporites in the core (Calaforra \& Pulido-
Bosch, 1999). Here, the collapse sinkholes and the calcium-sulfate springs are concentrated in the central part of the halokinetic structures, whereas the outer zones are characterized by broad subsidence depressions and springs with sodium chloride facies because of dissolution of Triassic halite and gypsum at depth (Fig. 6B).

The diapir salt structures have induced the development of deeply incised karstic canyons, like the Guadalhorce River canyon (Durán, 1984) and perched springs like the Cueva del Agua of Antequera (Calaforra \& Pulido-Bosch, 1989). The existence of halite at depth is evidenced by the hydrochemistry of the spring waters. The shallower halite deposits have been reached by boreholes at the depth of 100$200 \mathrm{~m}$ below the level of the Meliones Spring, which has a mean discharge of $1-2 \mathrm{~L} / \mathrm{s}$ and an electrical conductivity in excess of $200,000 \mathrm{mS} / \mathrm{cm}$ (Gutiérrez et al., 2004). This spring, located in the upstream sector of the Guadalhorce River reservoir, issues around 5,000-10,000 tons of sodium chloride per year, causing severe degradation of the reservoir waters that supply the city of Málaga (Gutiérrez et al., 2008). Probably both the gypsum and the halite were placed at a much deeper position in the past. Therefore, deep saline flows were responsible for the karstification of Sima del Águila.

Another important point to highlight briefly is that the Sima del Águila was subject to a disastrous environmental 'management', promoted by the Water Administration of the Southern Basin of Andalusia. The vicinity of the sinkhole was sealed and its entrance "lined" in order to prevent infiltration of water into its galleries and, therefore, to the nearby hypersaline spring of Meliones. For this purpose, several "antikarstic" measures were attempted to mitigate the problem, but with no success. For instance, several dolines and cave entrances, including the Sima del Águila (Fig. 6A), were sealed with compacted clays and concrete to reduce water infiltration. Obviously, this measure did not reduce the discharge in the Meliones spring, fed by deep underground flows (Fig. 6B), and caused a serious adverse impact on the karst environment (Calaforra \& Pulido-Bosch, 1999; Gutiérrez et al., 2008).

The Antequera Triassic outcrops also contain a large number of ephemeral lakes of great environmental value constituting the so-called "Betic endorheism" (Almécija, 1997; Calaforra, 2004). The origin of these closed depressions is largely related to subsidence phenomena caused by rising groundwater flows and dissolution of halite and gypsum. Calaforra (2004) links this phenomenon also to hyperkarstification processes (enhanced gypsum dissolution because of mixing of waters with different salinities and sulfate contents; Calaforra, 1998) of the gypsum caprock by upwelling of hypersaline groundwater (Fig. 6B), an aspect that has been taken into account in more recent works on the hydrogeology of the Triassic of Antequera (Andreo et al., 2016).

The most important aspects of the cave concern how its genesis is linked to the halokinetic processes themselves, and can be summarized as follows: 
1) The deepening of the sinkhole is related to the continual uplifting of the diapir itself. The salts - which are less dense - tend to form positive reliefs, helped by the local tectonics. In response to this groundlevel rise, the cavity continues to develop vertically in order to reach the local base level (Fig. 6A).

2) The cave passages do not cut into the halite levels; its waters are of the sulfate type and drain towards the reservoir close to the River Guadalhorce, but they do not contribute as significantly to the increase in salinity as the hypersaline springs that surround the diapir (Fig. 6B). The water flow in the cave can reach up to $40 \mathrm{~L} / \mathrm{s}$ after heavy rain events, but the base level is around 1-3 L/s and relatively stable in time.

3) The salt at depth is possibly connected with the formation of large chambers (like the last, 32-meter-deep shaft in the final reach of the Sima del Águila). These large chambers might have been generated due to the presence of deep saline waters that mixed with the sulfate waters, tripling the solubility of the gypsum up to $7 \mathrm{~g} / \mathrm{L}$ (Blount \& Dickson, 1973; Li \& Duan, 2011; Acero et al., 2013) and due to the common-ion effect by precipitation of carbonates forming huge flowstones on the shaft walls (Fig. 6.4).

\section{The Baena Gypsum Cave: hypophreatic genesis in gypsum}

The Baena Gypsum Cave, also known as Las Palomas Cave (Ramirez-Trillo, 1995; Mora-Luque et al., 2011; Mora-Luque, 2014), opens in the same lithological series as the Sima del Águila in Gobantes, but in a completely different geomorphological and hydrogeological setting.

The cave is situated in another large olistostromic block, where the gypsum breccias predominate. In this part, the carbonate blocks are less frequent and the texture of the gypsum is quite uniform, namely fine to medium-grained saccharoid gypsum facies. The overall appearance of the cave, especially if entering from the historic access passages (Fig. 7A) is of a cave of phreatic origin that has almost completely been silted up with sediment. This general assessment of its evolution is not wrong but it is incomplete. The descent to the lower levels, which currently is part of the tourist entrance, gives the key. The morphology of the cave changes completely with large chambers and large scallops that mark the direction of a very slow, rising flow.

Geomorphological evidence in the various sectors of the cave (Fig. 7) indicates that the cave was formed by a more complex process, in which rainfall infiltration was not directly involved in the formation of the cave (epigenetic cave) but rather the presence of groundwater in a confined aquifer (hypogenic cave). This process was controlled by the base level of the fluvial catchment, which was also related to the general evolution of the alluvial terraces of the River Guadalquivir on a larger scale, previously determined by Baena \& Díaz del Olmo (1994). Consequently, the cave can be considered as hypogenic - in the sense that it was formed by confined upward flow and not by vertical downward flow in an unconfined aquifer (Klimchouk, 2009).

While the order in which these zones developed over time is difficult to establish (they could also have formed at the same time), it is possible to conceptually divide the cave into three zones or "levels":

\section{Zone 1 (Zone of conduits and upper passages):} this is possibly one of the most recently developed conduits of the cave. This cave level is at least equivalent in age to those generated during the last stages of hypogenic formation, if we consider that the void of the cave would have been generated from the bottom up. The passages are narrow, or less wide and low, with smooth rounded walls, typical of phreatic and paragenetic conduits (Fig. 7A). Many of them are totally or partially filled with very fine, often clayey sediments. These detrital sediments are autochthonous in origin and remobilized from interbedded clay sediments of Triassic age, in a process similar to that observed in other hypogenic gypsum caves in Ukraine (Klimchouk, 1996, 2009, 2015).

The upper levels connect to the lower zone by means of vertical fractures that might have acted as "outlets" from the large lower chambers or on the contrary -"inlets (feeders)" towards these conduits (Fig. 7B).

Zone 2 (the great chambers zone): this is the lower level of large chambers, which are currently easily accessible, since they are equipped as a show cave (Fig. 7C). This is the zone of greatest dissolution in the cave and where the piezometric level has remained most constant over time, receiving inflow from beneath. These large chambers are partially filled with large quantities of sediment. These sediment banks are certainly linked to fluctuations in the fluvial flow associated with the hydrogeological context of the cave, which must have marked the fluctuation in base level and therefore of the gypsum aquifer and the cave.

Zone 3 (the lakes zone): its name refers to the present-day levels of the lakes, but which during the geological past would have behaved as water inflow fractures ("feeders") to the cave. They reflect the current piezometric level controlled by the river and its fluctuations in flow (Fig. 7D). Clearly, this is the least explored zone, but its presence indicates that the confined artesian flow was distributed out from this zone and slowly generated the gypsum cave.

Nevertheless, within the general scheme (Fig. 7.1) there are still many questions to be answered, including, 'What is the relationship between the Pliocene and Quaternary fluctuations of the base level of the cave and their age?', 'What materials confined the gypsum levels and what comprised the lower aquifer that fed the system?'. In general, we can hypothesize that the cave was formed in a single, hydraulically isolated olistostromic block, where the 

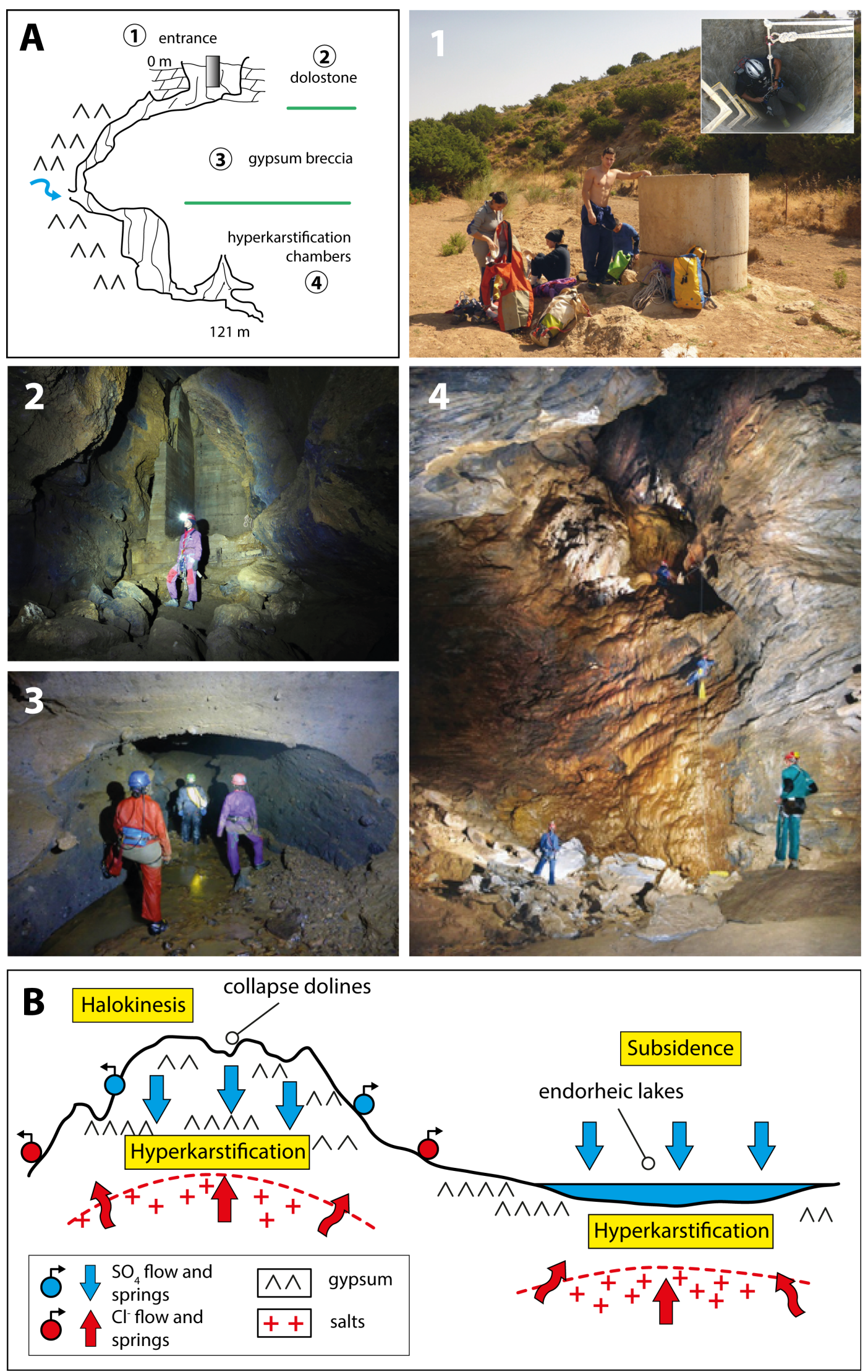

Fig. 6. Relationship between gypsum karstification, hyperkarstification and diapirism in the Triassic of Antequera (Málaga); A) Cross section of the Sima del Águila (Ramírez-Trillo, 1995) with the different levels of dolostone at the entrance and gypsum galleries and large chambers at the bottom; B) The large sinkholes like the Sima del Águila are on the gypsum "caprock" of the diapir with associated sulfate springs. The hypersaline springs suggest the possibility, at depth, of saline hyperkarstification in gypsum due to the presence of halite masses; 1): The entrance of the Águila sinkhole was sealed with concrete tubes to avoid infiltration to the hypersaline aquifer, obviously with no success; 2): The entrance shaft follows a contact between Triassic dolostone and gypsum before reaching the gypsum breccia galleries; 3 ): View of the olistostromic gypsum breccia in which the cave developed. The galleries consist of microcrystalline gypsum matrix and pebbles of all types of redeposited, earlier lithologies; 4): Large chamber [hyperkarstification (?) and common ion effect (?)] near the end of the Sima del Águila containing a large carbonate flowstone. Photos courtesy of Sociedad de Espeleólogos Granadinos $(1,2$, and 3$)$ and Víctor Ferrer (4). 
materials surrounding the olistolite have been acting as feeders (bottom) and impervious caprock (above) of the gypsum block in a general context of terrace level fluctuations of the River Guadalquivir. However, a polygenetic origin of the Baena Gypsum Cave, including paragenetic and epigenetic mechanisms, cannot be ruled out and further investigations will be necessary to shed light on the formation of this cavity.
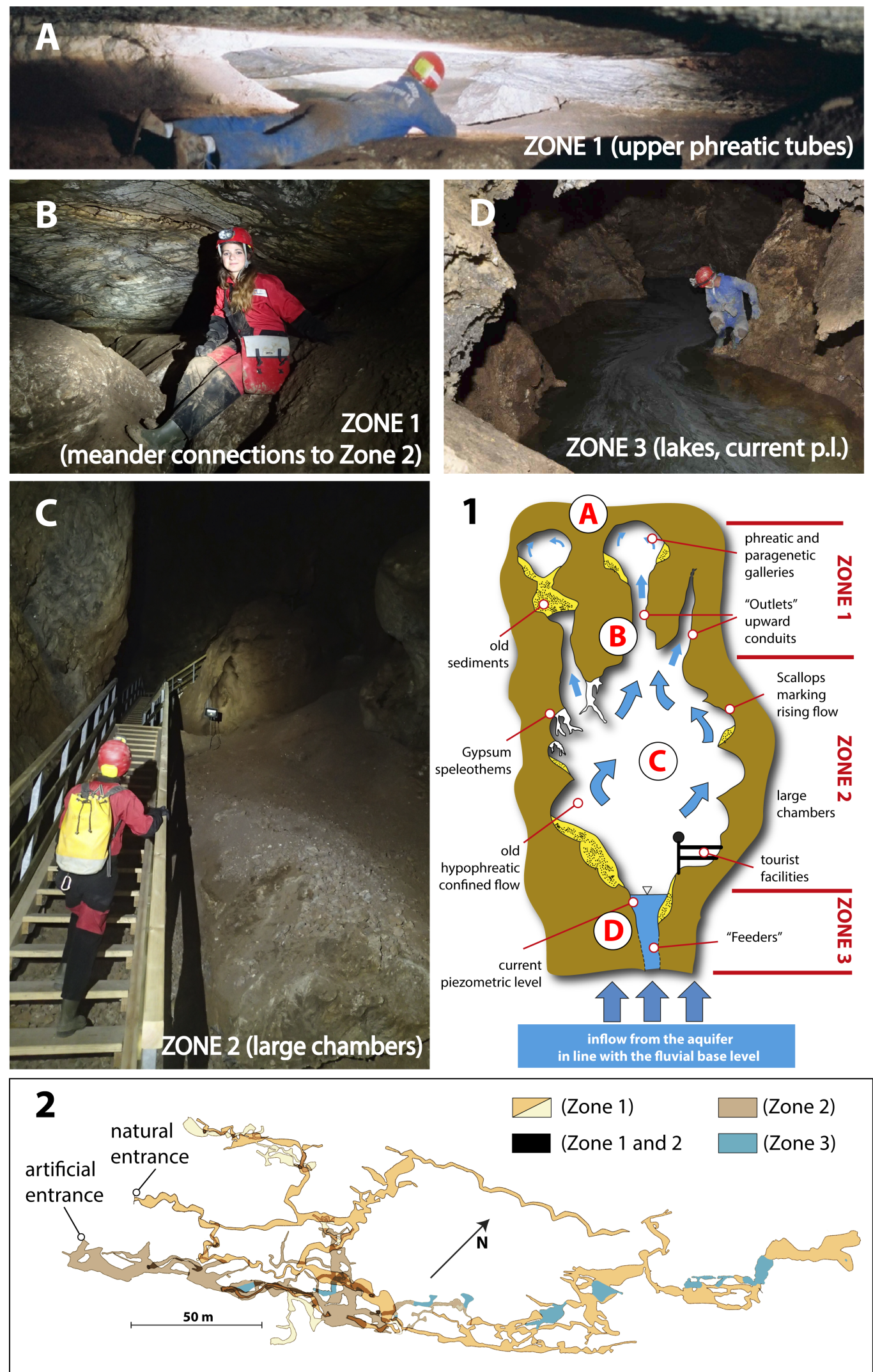

Fig. 7. Various speleogenetic zones in the Baena Gypsum Cave. A) Zone 1. Upper phreatic and paragenetic galleries and narrow passages, containing clay sediment infillings; B) Connections with lower zones are via narrow vertical shafts; C) Zone 2. Large dissolution chambers (the zone currently equipped for tourism) with large banks of sediment filling the cave; D) Zone 3. Lakes indicate the current piezometric level and the old vertical inflow conduits. 1): speleogenetic scheme for the Baena Gypsum Cave. The development of the cave occurred from the bottom upwards, under confined hypophreatic conditions. Relationships between the various zones is differentiated; 2): Cave map showing the position of the different levels surveyed (map based on the survey made by the G40 Speleological Group, after Mora-Luque et al., 2011). 


\section{SPELEOGENETIC CLASSIFICATION OF GYPSUM CAVES}

A simple way to group the various types of gypsum caves according to their speleogenesis was initially proposed by Calaforra (1998) and is revised and extended in the present paper. It should be noted that the present classification is not intended as a closed system in which each cave is circumscribed to a single speleogenetic group. Obviously, many intermediate interpretation cases are possible.

Gypsum caves can be initially differentiated into two groups - those in which lithology (e.g., bedrock stratification) is the dominant determinant, and those controlled by tectonic activity in the area (Fig. 8). The different cave models diverge from a general scheme, where the gypsum strata or series of strata comprising the karstic gypsiferous formation occur between a permeable layer above (or even no overlying layer in the present day) and an underlying material that can either be permeable or impermeable. Based on this general scheme a variety of hypotheses can be developed to explain the subsequent speleogenesis that affected the rocks. Obviously, some cave systems can be linked to various stages throughout their speleological history.

a) Gypsum multi-strata caves. Gypsiferous materials interstratified with marls, which have undergone various phreatic and vadose speleogenetic phases in multilayer aquifers. There are several examples of this in the gypsum karst of Sorbas where cave passages follow the dip of the strata (Calaforra \& PulidoBosch, 2003). Examples in other regions include some interlayer cavities in the Emilia Romagna gypsum outcrops (NE Italy), although in this case the cave systems (e.g., Grotta de la Spipola) are developed in one or two gypsum/marl strata that are inclined by $40-60^{\circ}$. Here, the speleogenesis was strongly controlled by tectonics and paragenesis and frequently share characteristics with "multi-base level cave" typology (Columbu et al., 2015, 2017; De Waele et al., 2017).

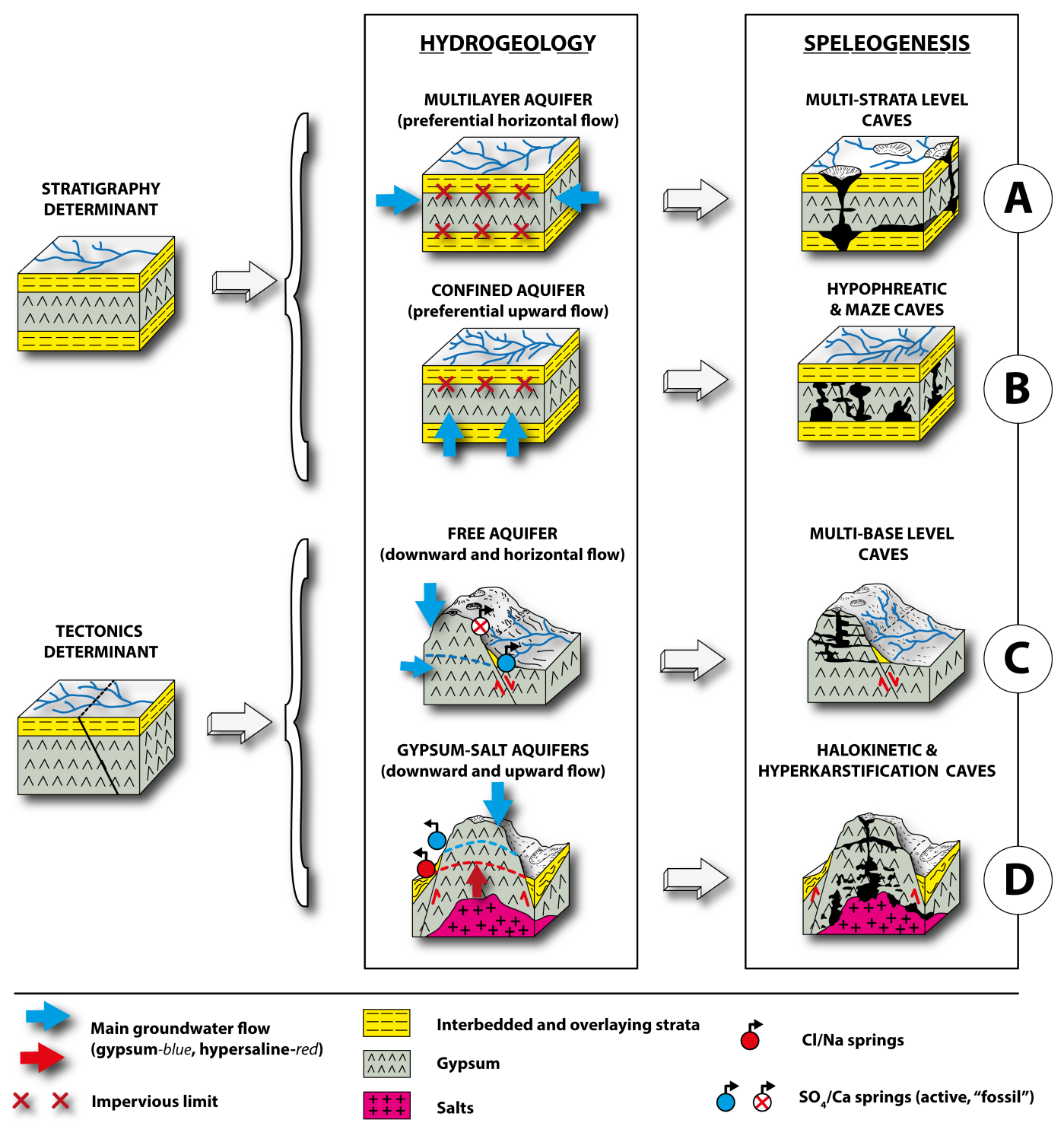

Fig. 8. Speleogenetic classification of gypsum caves (see text for discussion). Gypsum caves are previously divided in two general groups: Stratigraphy determinant or Tectonics determinant. Following the hydrogeological behavior and evolution of the landscape and geological formations the caves are divided into A) Caves with multi-strata control and multilayer aquifer; B) Caves of hypophreatic origin and confined aquifer; C) Caves controlled by the fluctuation of the regional base-level under free aquifer hydrogeological conditions and, D) Caves developed in a context of uplift by halokinetic and hyperkarstification processes. See text for discussion and examples worldwide. 
b) Gypsum hypophreatic and maze caves. These caves result from a confined system that is capped by an impervious/semi-impervious material. The karstificable materials receive an inflow of water from below (artesian-hypophreatic, "hypogenic sensu lato"), which leads to the development of a labyrinthine configuration and typical morphology of "feeders and outlets". A novel example - in as much as it is the first time this cavity is described from this speleogenetic point of view - is the Cueva del Yeso of Baena, described in this paper. Other previous examples are the Estremera Cave (Tajo Basin) (Calaforra \& Pulido-Bosch, 1989; Calaforra, 1998; Gutiérrez et al., 2004; 2008) the labyrinthine macro-cavities ("maze caves") of Podolia in the Ukrainian gypsum karst (Klimchouk, 1996, 2009, 2015), the confined aquifer of Coffee Cave in New Mexico (Stafford et al., 2008a) the Moncalvo Cave in Piedmont, Italy (Vigna et al., 2010a,b; De Waele et al., 2017), the cave in Monticello d'Alba (Banzato et al., 2017; De Waele et al., 2017), and the gypsum/anhydrite hypogenic caves of the Zechstein karst of the South-Harz region, Germany (Kempe, 1996).

c) Gypsum multi-base level caves. Occasionally the multilayer configurations described in a) above are strongly controlled by the base level fluctuation (usually downward) but the lithological component does not play the main role in the multilevel configuration. One clear example of this type of evolution described in the present paper is the Barranco del InfiernoCueva del Yeso system, but the best examples have been described in the Messinian outcrops of Emilia Romagna, including the Monte Tondo-Re Tiberio cave system (Columbu et al., 2015, 2017; De Waele et al., 2017), Grotta della Spipola and Rio Basino-Rio Stella (De Waele et al., 2017) and the Monte Conca in Sicily (Vattano, 2004, 2008; Madonia \& Vattano, 2011). The epiphreatic gypsum caves where only one, well-developed cave base-level is apparently present, with horizontal conduits and circular and paragenetic sections, could be considered as a subtype of this group of caves. They are frequently linked to the evolution of a river, which has marked their recent speleological history and cave morphology. Some examples of such cave conduits are the Mosquera Cave in Beuda (Girona, Spain) (Calaforra \& Pulido-Bosch, 1989; Miret \& García, 1999), the Rio Stella-Rio Basino in Emilia Romagna (Forti, et al., 1989; De Waele, 2010, 2017), the Grave Grubbo-Vallone Cufalo in Calabria (Ferrini \& Pasqua, 1998; Ferrini \& Moretti, 2003), the actual Aquafredda level in the Spipola cave system (De Waele et al., 2017) and the Parks Ranch Cave in the gypsum plain of New Mexico related to the Black River (Calaforra \& Forti, 1994; Calaforra, 1998). Interestingly, this last example of gypsum multi-base level cave also shows vestiges of an early hypogene genesis (Stafford et al., 2008b).

d) Gypsum halokinetic caves whose speleogenesis is linked to the presence of halokinetic (diapiric) phenomena that produce a continuous upward movement on a large geological scale. In consequence, deepening of the caves in an essentially vertical and vadose development is expected. Spectacular examples have been described in the Triassic gypsum karst of Antequera (Málaga) (Calaforra \& Pulido-Bosch, 1993, 1999; Andreo et al., 2016) and the "Túnel dels Sumidors" of Vallada in the province of Valencia (Calaforra et al., 1986; Calaforra \& Pulido-Bosch, 1989). Nevertheless, one of the finest European examples of caves and halokinesis is described in the Val di Secchia (N Italy), which is comparable to the Spanish examples in terms of their speleogenesis, but which lies in the active tectonic zone of the Northern Apennines (AA.VV., 1988; Chiesi et al., 2010) and shows evidence of gypsum hyperkarstification processes (Calaforra, 2004) by mixing of sulfate (gypsum and/or anhydrite), carbonate (limestone and/or dolostone) and chloride (halite and other salts) waters typical of Triassic aquifers in the Alpine tectonic context.

\section{CONCLUSION}

Interest in the study of gypsum karst has been growing steadily since the early 1980s and especially in those regions and countries with potential research and great profusion of gypsum outcrops, such as Italy, Spain, Ukraine, and USA. Nowadays, numerous studies have been placing gypsum karst research as a new source of knowledge regarding karstological and speleogenetic processes, contributing interesting relationships to the classic studies of speleogenesis in carbonate rocks.

Accordingly, the related studies in the gypsum karst of these countries, using examples from the Triassic and Messinian outcrops of Spain along with references to the Italian, Ukrainian and North American gypsum karsts have been used to compile this synthetic article. There are many other examples of gypsum karst around the world that are now being studied step by step, such as those located in Central Asia, North Africa and South America. All these regions, still to be explored from the point of view of gypsum karst, have a very promising future and we are certain that it will lead to new advances and discoveries regarding gypsum speleogenesis.

In the present study, and in accordance with the above limitations, we have tried to provide an overview of the context in which gypsum karst can be developed, through a speleogenetic classification with a clearly hydrogeological and geomorphological basis. The four different typologies of gypsum karst described here are not intended to be a closed system. There are certainly many examples and their number will grow as knowledge of gypsum karst advances. In any case, we consider that this classification can be valid at least for an initial identification of the varied and sometimes unusual speleogenetic processes that can occur in the geological history of a gypsum karst. 


\section{ACKNOWLEDGEMENTS}

This work and general approach to the hydrogeological classification of gypsum caves has been possible thanks to the efforts of cavers all around the world. Their mapping, surveying and exploration of caves allowed researchers to present their speleogenetic hypotheses on a real scientific basis. This is especially true for research carried out not only in Spain, but also in Italy, Ukraine and USA where the advances in gypsum karstology have always received worldwide recognition. The authors thank all the groups and researchers cited in the manuscript. Special thanks go to the Espeleo-Club Almería (ECA), Grupo Espeleológico Provincial (GEP), Secció de Exploracions Subterranies de Terrassa (SIS), Grupo de Esploraciones Subterráneas de la Sociedad Excursionista de Málaga (GES de la SEM) and Grupo de Espeleólogos Granadinos (GEG) for providing the detailed cave maps. Also, we wish to thank Paco Hoyos and Victor Ferrer for the excellent photographs that illustrate the figures and which improve and enhance our text and the general discussion in the article. The authors appreciate the suggestions made by Professor Kevin W. Stafford, Dr. Juan Antonio Barberá, Professor Jo De Waele and an anonymous reviewer, which helped to improve the manuscript.

\section{REFERENCES}

AA.VV., 1988 - L'area carsica dell'Alta Val di Secchia: studio interdisciplinare dei caratteri ambientali. Regione Emilia-Romagna Studi e documentazioni, 304 p.

Acero P., Gutiérrez F., Galve J.P., Auqué L.F., Carbonel D., Gimeno M.J., Gómez J.B., Asta M.P. \& Yechieli Y., 2013 - Hydrogeochemical characterization of an evaporite karst area affected by sinkholes (Ebro Valley, NE Spain). Geologica Acta, 11 (4): 389-407.

Almécija C., 1997 - Hydrological and hydrochemical study of the wetland complexes at the north of the province of Malaga. Unpublished Ph.D. Thesis, University of Granada.

Andreo B., Gil-Márquez J.M., Mudarra M., Linares L. \& Carrasco F., 2016 - Hypothesis on the hydrogeological context of wetland areas and springs related to evaporitic karst aquifers (Málaga, Córdoba and Jaén provinces, Southern Spain). Environmental Earth Sciences, 75: 1-19. https://doi.org/10.1007/s12665-016-5545-1

Ayuso I., Calaforra J.M., Gutiérrez-Labouret M. \& Torres A., 2014 - Cuevas y Simas del Karst en Yeso de Sorbas. Itinerarios y Travesías Espeleológicas - I. Espeleo Club Almería (ECA), Almeria.

Baena R. \& Díaz del Olmo F., 1994 - Cuaternario aluvial de la depresión del Guadalquivir: episodios geomorfológicos cronología paleomagnética. Geogaceta, (15): 102-104.

Banzato C., Vigna B., Fiorucci A. \& De Waele J., 2017 - Hypogene gypsum caves in Piedmont (N-Italy). In: Klimchouk A.B., Palmer A.N., Audra P., De Waele J. $\&$ Auler A. (Eds.), Hypogene karst regions and caves of the world. Springer, p. 211-224.

Baggley K.A., 2000 - The late Tortonian-Early Messinian foraminiferal record of the Abad Member (Turre formation), Sorbas Basin, Almeria, South-East Spain. Palaeontology, 43 (6): 1069-1112.

https://doi.org/10.1111/1475-4983.00162
Blount C.W. \& Dickson F.W., 1973 - Gypsum-anhydrite equilibria in systems $\mathrm{CaSO}_{4}-\mathrm{H}_{2} \mathrm{O}$ and $\mathrm{CaSO}_{4}-\mathrm{NaCl}-\mathrm{H}_{2} \mathrm{O}$. American Mineralogist, 58 (3-4): 323-331.

Braga J.C., Baena J., Calaforra J.M., Coves J., Dabrio C., Freixas C., Fernández-Soler J.M., Gómez-Navarro J.A., Goy J.L., Harvey A., Martín J.M., Martí-Penela A., Mather A., Stokes M., Villalobos M. \& Zazo C., 2003 - Geology of the arid zone of Almeria (South Spain). An educational field guide. Regional Ministry of Environment, Seville, 163 p.

Calaforra J.M., 1995 - El Sistema Covadura (Karst en Yesos de Sorbas). Tecno Ambiente, 48: 73-80.

Calaforra J.M., 1996 - Contribución al conocimiento de la karstologia de yesos. Ciencia y Tecnología, University of Almeria, Almeria.

Calaforra J.M., 1998 - Karstología de yesos. Monografias Ciencia y Tecnología, University of Almeria, Almeria, 392 p.

Calaforra J.M., 2003a - The fluvio-karst Barranco del Infierno and Cueva del Yeso. In: Andalucía C.d.M.A.d.1.J.d. (Ed.), Geology of the arid zone of Almeria (Southern Spain). An educational field guide. Consejeria de Medio Ambiente de la Junta de Andalucía, Seville, p. 124-125.

Calaforra J.M., 2003b - El karst en yeso de Sorbas: un recorrido subterráneo por el interior del yeso - The gypsum karst of Sorbas: a subterranean journey through the interior of gypsum. Consejería de Medio Ambiente de la Junta de Andalucía, 83 p.

Calaforra J.M., 2004 - A conceptual model proposal to the Trias of Antequera Karst. Workshop in Triassic sediments hydrogeology and its influence over wetland system functioning in the norther sector of the province of Málaga, p 45-47.

Calaforra J.M. \& Forti P., 1994 - Two new types of gypsum speleothems from New Mexico: gypsum trays and gypsum dust. NSS Bulletin, 56 (1): 32-37.

Calaforra J.M., Garay P. \& González-Ríos M.J., 1986 Observaciones sobre las topografias realizadas en el "Túnel dels Sumidors" (Valencia). El mayor desnivel mundial en yesos. Lapiaz, p. 22-27.

Calaforra J.M. \& Pulido-Bosch A., 1988 - Sintesis hidrogeologica sobre los yesos karstificados de Sorbas y su entorno (Almeria, Espa na). Boletin del Instituto de Estudios Almerienses. Ciencias, p. 33-48.

Calaforra J.M. \& Pulido-Bosch A., 1989 - Principales sistemas kársticos en yesos de España. El Karst en España: Monografias de la Sociedad Española de Geomorfologia, p. 277-294.

Calaforra J.M. \& Pulido-Bosch A., 1993 - The hydrogeochemistry and morphology of the Triassic gypsum in the Salinas-Fuente Camacho area. In: Pulido-Bosch A. (Ed.), Some Spanish karstic aquifers. University of Granada, Granada, p. 67-83.

Calaforra J.M. \& Pulido-Bosch A., 1996 - Some examples of gypsum karsts and the more important gypsum caves in Spain. International Journal of Speleology, 25 (3): 225-237. https://doi.org/10.5038/1827-806X.25.3.17

Calaforra J.M. \& Pulido-Bosch A., 1999 - Gypsum karst features as evidence of diapiric processes in the Betic Cordillera, Southern Spain. Geomorphology, 29 (3-4): 251-264.

https://doi.org/10.1016/S0169-555X(99)00019-7

Calaforra J.M. \& Pulido-Bosch A., 2000 - Cave development in vadose settings in a multilayer aquiferthe Sorbas karst, Almeria, Spain. In: Klimchouk A.B., Ford D.C., Palmer A.N. \& Dreybrodt W. (Eds.), Speleogenesis, evolution of karst aquifers. National Speleological Society, Huntsville, Alabama, p. 382-386. 
Calaforra J.M. \& Pulido-Bosch A., 2003 - Evolution of the gypsum karst of Sorbas (SE Spain). Geomorphology, 50 (1-3): 173-180. https://doi.org/10.1016/S0169-555X(02)00213-1

Calaforra J.M., Pulido-Bosch A., Campoy P., Cortés A., Fernández-Cortés A., Gázquez F., Guirado E. \& Tarnawa E., 2015 - Notas sobre la espeleogénesis de las cavidades en yeso de Andalucía. Jornadas sobre el Karst en Yeso - Gypsum Karst Workshop "Baena 2015". Diputación de Córdoba y Ayuntamiento de Baena, Baena (Córdoba, Spain), p. 14-27.

Calaforra J.M., Pulido-Bosch A. \& López-Chicano M., 2002 - Gypsum karst in the Betic Cordillera (South Spain). Carbonates and Evaporites, 17 (2): 134-141. https://doi.org/10.1007/BF03176479

Carrasco F., Durán J.J., Calaforra J.M. \& Duran J.J., 2007 - Trias of Antequera. Hydrogeological Atlas of the province of Malaga, vol 2. Diputación Provincial de Málaga-IGME-UMA: p. 205-210.

Chiesi M., De Waele J. \& Forti P., 2010 - Origin and evolution of a salty gypsum/anhydrite karst spring: The case of Poiano (Northern Apennines, Italy). Hydrogeology Journal, 18 (5): 1111-1124. https://doi.org/10.1007/s10040-010-0576-2

Clauzon G. \& Estrada F., 2015 - New insights on the Sorbas Basin (SE Spain): The onshore reference of the Messinian Salinity Crisis. Marine and Petroleum Geology, 66 (Part 1): 71-100.

https://doi.org/10.1016/j.marpetgeo.2015.02.016

Columbu A., Chiarini V., De Waele J., Drysdale R., Woodhead J., Hellstrom J. \& Forti P., 2017 - Late quaternary speleogenesis and landscape evolution in the northern Apennine evaporite areas. Earth Surface Processes and Landforms (in press).

https://doi.org/10.1002/esp.4099

Columbu A., De Waele J., Forti P., Montagna P., Picotti V., Pons-Branchu E., Hellstrom J., Bajo P. \& Drysdale R., 2015 - Gypsum caves as indicators of climate-driven river incision and aggradation in a rapidly uplifting region. Geology, 43 (6): 539-542.

https://doi.org/10.1130/G36595.1

Dabrio C.J. \& Polo-Camacho M.D., 1995 - Oscilaciones eustáticas de alta frecuencia en el Neógeno superior de Sorbas (Almería, sureste de España). Geogaceta, 18: $75-78$.

Dell'Aglio A., 1993 - Misure sperimentali di erosione chimica nei gessi: il carso secco temperato di Sorbas (Almeria, Spagna). Dipartimento di Scienze della Terra e Geologico Ambientali, University of Bologna, Bologna, p. 90.

De Waele J., 2010 - Speleogenesi del Complesso Carsico Rio Stella-Rio Basino. Memorie dell'Istituto Italiano di Speleologia, II (23): 95-108.

De Waele J., Piccini L., Columbu A., Madonia G., Vattano M., Calligaris C., D’Angeli I., Parise M., Chiesi M., Sivelli M., Vigna B., Zini L., Chiarini V., Sauro F., Drysdale R. \& Forti P., 2017 - Evaporite karst in Italy: a review. International Journal of Speleology, 46 (2): 137-168. https://doi.org/10.5038/1827-806X.46.2.2107

Dronkert H., 1976 - Late Miocene evaporites in the Sorbas Basin and adjoining areas. Memorie Società Geologica Italiana, 16: 341-361.

Dronkert H., 1977 - The evaporites of the Sorbas Basin. Revsita del Instituto de Investigaciones Geológícas, (33): 55-76.

Durán J.J., 1984 - Evolución geomorfológica del cañón del rio Guadalhorce en el Trías de Antequera (Archidona, Málaga). Cuadernos de Investigación Geográfica, p. 42-55.
Ferrini G. \& Moretti A., 2003 - Calabria. Memorie dell'Istituto Italiano di Speleologia, II (14): 243-252.

Ferrini G. \& Pasqua P., 1998 - Il complesso carsico Grave Grubbo - risorgiva Vallone Cufalo (gessoareniti altomessiniane del Bacino Crotonese - Calabria): relazioni tra stratigrafia ed evolucione speleogenetica. In. IV Congresso Nazionale di Speleologia, Chiusa di Peso (Italy), 181-184.

Forti P., Francavilla F., Prata E., Rabbi E. \& Griffoni A., 1989 - Evoluzione idrogeologica dei sistemi carsici dell'Emilia-Romagna: il complesso Rio Stella-Rio Basino (Riolo Terme, Italia). Atti XV Congresso Nazionale di Speleologia, p. 349-368.

Gázquez F. \& Calaforra J.M., 2014 - The gypsum karst of Sorbas, Betic Chain. In: Gutierrez, F. \& Gutierrez, M. (Eds.) Landscapes and landforms of Spain, Springer p. 127-135.

https://doi.org/10.1007/978-94-017-8628-7 10

Gázquez F., Calaforra J.M., Forti P., De Waele J., Sanna L., 2015 - The role of condensation in the evolution of dissolutional forms in gypsum caves: study case in the karst of Sorbas (SE Spain). Geomorphology, 229: 100111. https://doi.org/10.1016/j.geomorph.2014.07.006

Gázquez F., Calaforra J.M. \& Fernández-Cortés A., 2016 - Flash flood events recorded by air temperature changes in caves: a case study in Covadura Cave (SE Spain). Journal of Hydrology, 541: 136-145.

https://doi.org/10.1016/j.jhydrol.2015.10.059

Gutiérrrez F., Calaforra J.M., Cardona F., Orti F., Duran J.J. \& Garay P., 2008 - Geological and environmental implications of the evaporite karst in Spain. Environmental Geology, 53 (5): 951-965. https://doi.org/10.1007/s00254-007-0721-y

Gutiérrez F., Calaforra J.M., Cardona F., Ortí F., Durán J. \& Garay P., 2004 - El karst en las formaciones evaporiticas españolas. Investigaciones en sistemas kársticos españoles. IGME, Madrid, p. 49-87.

Gutiérrez F., Calaforra J.M., Cardona F., Ortí F., Durán J.J. \& Garay P., 2008 - Geological and environmental implications of the evaporite karst in Spain. Environmental Geology, 53 (5): 951-965. https://doi.org/10.1007/s00254-007-0721-y

Kempe S., 1996 - Gypsum karst in Germany. International Journal of Speleology, 25 (3-4): 49-60.

Klimchouk A., 1996 - Gypsum karst in the Western Ukraine. International Journal of Speleology, 25 (3): 263-278.

https://doi.org/10.5038/1827-806x.25.3.16

Klimchouk A., 2009 - Morphogenesis of hypogenic caves. Geomorphology, 106 (1-2): 100-117.

https://doi.org/10.1016/j.geomorph.2008.09.013

Klimchouk A., 2015 - Gypsum karst of the Western Ukraine. A model example of hypogene artesian speleogenesis. Jornadas sobre Karst en Yeso - Gypsum Karst Workshop "Baena 2015”. Diputación de Córdoba and Ayuntamiento de Baena, Baena (Córdoba, Spain), p. 54-67.

Li J. \& Duan Z.H., 2011 - A thermodynamic model for the prediction of phase equilibria and speciation in the $\mathrm{H}_{2} \mathrm{O}-\mathrm{CO}_{2}-\mathrm{NaCl}-\mathrm{CaCO}-\mathrm{CaSO}_{4}$ system from $\mathrm{O}$ to 250 degrees $\mathrm{C}, 1$ to 1000 bar with $\mathrm{NaCl}$ concentrations up to halite saturation. Geochimica et Cosmochimica Acta, 75 (15): 4351-4376.

https://doi.org/10.1016/j.gca.2011.05.019

Madonia G. \& Vattano M., 2011 - New knowledge on the Monte Conca gypsum karst system (central-western Sicily, Italy). Acta Carsologica, 40 (1): 53-64. https://doi.org/10.3986/ac.v40i1.28 
Miret F. \& García M., 1999 - Coves de l'Alta Garrotxa. Grupo d'Espeleologia de Badalona (GEB), Badalona, Spain.

Mora-Luque J.A., 2014 - La Cueva del Yeso de Baena: ejemplo de conservación y protección. In: Calaforra J.M.D. (Ed.), Cuevatur - I Congreso Iberoamericano y $\mathrm{V}$ Congreso Español sobre Cuevas Turísticas. Asociación de Cuevas Turísticas Españolas (ACTE), Aracena (Huelva), p. 159-168.

Mora-Luque J.A., Van Heiningen M., Bermúdez R., RuízRuano F. \& Alcalá-Ortiz A., 2011 - Cueva del Yeso de Baena. Colección Baena Cultura, Ayuntamiento de Baena, Baena (Córdoba, Spain), 112 p.

Pérez-López A. \& Sanz de Galdeano C., 1994 - Tectonics of the Triassic materials at the central area of Subbetic Domain (Betic Cordillera). Revista Sociedad Geológica, 7 (1-2): 141-153.

Ramírez-Trillo F., 1995 - Grandes cavidades en la provincia de Málaga. Espeleotemas, 5: 71-94.

Rodríguez-Fernández J., Roldán F.J., Azañón J.M. \& Garcia-Cortés A., 2013 - Gravitational collapse of the alpine subbetic orogenic front, during the Middle-Upper Miocene: The Subbetic Extensional Complex. Boletin Geologico y Minero, 124 (3): 477-504.

Sanna L., Gázquez F. \& Calaforra J.-M., 2012 - A geomorphological and speleological approach in the study of hydrogeology of gypsum karst of Sorbas (SE Spain). Geografia Fisica e Dinamica Quaternaria, 35 (2): 153-166.

https://doi.org/10.4461/GFDQ.2012.35.14
Sanna L., De Waele J., Calaforra J. M. \& Forti, P., 2015 Long-term erosion rate measurements in gypsum caves of Sorbas (SE Spain) by the Micro-Erosion Meter method. Geomorphology, 228: 213-225.

https://doi.org/10.1016/j.geomorph.2014.09.009

Stafford K.W., Land L. \& Klimchouk A., 2008a-Hypogenic speleogenesis within Seven Rivers evaporites: Coffee cave, Eddy county, New Mexico. Journal of Cave and Karst Studies, 70 (1): 47-61.

Stafford K.W., Rosales-Lagarde L. \& Boston P.J., 2008b - Epigene and hypogene gypsum karst manifestations of the Castile Formation: Eddy County, New Mexico and Culberson County, Texas, USA. International Journal of Speleology, 37 (2): 83-98. https://doi.org/10.5038/1827-806X.37.2.1

Vattano M., 2004 - Geomorphological aspects of Monte Conca Karst system (Caltanissetta, Sicily). Memorie dell'Istituto Italiano di Speleologia, 2 (16): 103-104.

Vattano M., 2008 - Geomorphological evolution of evaporite karst areas in south-central Sicily by relationship analysis between hypogean karst landforms and surface landforms. Unpublished Ph.D. Thesis, Univeristy of Palermo, 250 p.

Vigna B., Fioraso G., De Waele J. \& Banzato C., 2010a - Evolution of karst in Messinian gypsum (Monferrato, Northern Italy). Geodinamica Acta, 23 (1-3): 29-40. https://doi.org/10.3166/ga.23.29-40

Vigna B., Fiorucci A., Banzato C., Forti P. \& De Waele J., $2010 \mathrm{~b}$ - Hypogene gypsum karst and sinkhole formation at Moncalvo (Asti, Italy). Zeitschrift für Geomorfologie, 54 (2): 285-306. https://doi.org/10.1127/0372-8854/2010/0054S2-0015 